\title{
'TAXONOMIC ALGAL DIVERSITY OF FAMILIES GOMPHONEMATACEAE, NITZSCHIACEAE AND SURIRELLACEAE ORDER PINNELES IN DIMBHE DAM FROM AMBEGAON TEHSIL OF PUNE DISTRICT (MAHARASHTRA)'
}

\author{
${ }^{1}$ Radhakishn Namdeo Tagad and 2 Ramchandra H. Bhoge \\ ${ }^{1}$ Department of Botany, Hon. B. J. College, Ale, Tal. Junnar, Dist. Pune 412411 \\ ${ }^{2}$ Aided Junior College, Taleran, Tal. Junnar, Dist. Pune 412411 \\ *Corresponding Author: tagadrn@gmail.com
}

\begin{abstract}
:
The Ambegaon tehsil in Pune District situated in between 1907'0" Northern $73^{\circ} 44^{\prime} 0^{\prime \prime}$ Eastern latitude on the northern part of Deccan Plateau \& composed of undulating hills. Ambegaon tehsil covers the area from Bhimashankar to Lakhanpur. This tehsil has survived with the blessings of Kulguru Shree Khanderaiya of Bhimashankar. Agriculture is the main occupation of this region. Adivasi Tribes found in large number in this region. Periodical collections of algae from the study area were done from the Dimbhe dam as well as Rivers, Lake's, Puddles, Pulls etc. from Ambegaon Tehsil. Sampling stations were carried away. The samples were bringing to laboratory for identification; Identification were done with the help of Indian monographs other standard literature like Sarode and Kamat (1984). The collected algal forms had been preserved in $4 \%$ formalin. With the help of phytoplankton collected samples were investigated from September 2018 to October 2019. The present investigation is undertaken with keep in mind that to study the algal population from selected stations of study area. All algal plants were identified up to genus, species, variety as well as forma level. We visit all stations from Ambegaon Tehsil. Attempts have been undertaken to bring out the Algal flora of this region. There are 23 species, 18 varieties and 1 forma belonging to 5 genera of 3 families from 1 order of 1 class from 1 division. Family Nitzschiaceae includes 2 genera, 6 species and 6 varieties. Family Surirellaceae include only 2 genera and 7 species and 2 variates. While family Gomphonemataceae include only 1 genus and 10 species, 10 varieties and 1 forma While Gomphonema is more densely occur in Ambegaon tehsil. But Genus Cymatopleura include only 1 species occur in Ambegaon tehsil.
\end{abstract}

Key words: Pinneles, Ambegaon, Pune, Gomphonemataceae, Nitzschiaceae, Surirellaceae, Dimbhe dam

\section{INTRODUCTION:}

Filamentous algae were collected from mass growths by hand. Sub-aerial algae growing attached to tree barks, on damp walls or other such substrata were collected by scraping with a scalpel and then picked up with the help of a forceps. Hand collected samples were investigated from September 2018 to October 2019. The present investigation is undertaken with keep in mind that to study the algal population from selected stations of study area.

MATERIALS AND METHODS:
The samples were preserved in a mixture of $50 \mathrm{ml}$ of $95 \%$ ethyl alcohol, $5 \mathrm{ml}$ of glacial acetic acid, $10 \mathrm{ml}$ of $40 \%$ commercial formalin and $35 \mathrm{ml}$ of water. The specimens are observed under microscope for 10X, 40X, 100X and Photographs were taken with the help digital camera under appropriate magnifications. Identification of specimens was mostly based on the keys given in standard monographs \& literatures. The Vaucher specimens have been deposited at Dept. of Botany, Hon. Baladaheb Jadhav College, Ale, Tal. Junnar, Dist. Pune.

Periodical collections of algae from the study area were done from the Dams as well 
as Rivers, Lake's, Puddles, Pulls etc. from Ambegaon Tehsil. Sampling stations were carried away. The samples were bringing to laboratory for identification; Identification was done with the help of Indian monographs and other standard literature like Anand (1998) and Sarode and Kamat (1984). The collected algal forms had been preserved in $4 \%$ formalin.

Algal samples were collected from various freshwater biotopes viz. ditches, puddles, pools, ponds, reservoirs, waterfalls, streams, rivers, paddy fields, moist soil, swamps and marshes of Study area. Phytoplanktons were collected by using phytoplankton net from surface waters of impoundments.

\section{SUMMARY AND CONCLUSION:}

Since the dawn of civilization, water has been the most important raw material for civilization. It is one of the vital sources of all kinds of life on the earth. Economically, culturally and biologically water is most useful natural resource on the earth. We use water for drinking, bathing, cooking, cooling, irrigation, transportation, energy power and recreation. Thus, water is nature's gift to the living world including human race. Our biosphere consists of $71 \%$ of water out of which fresh water environment occupied only $2.6 \%$. For the usable purpose only $0.62 \%$ water from lakes, streams, rivers and other resources are available for the living organisms.

In India most of the cities, towns, villages and industries are situated at the bank of rivers and lakes. Due to uncontrolled population, the huge quantity of untreated sewage is being added every day in these different water reservoirs. Besides these, industrial wastes, residues of insecticides, pesticides, excess agricultural fertilizers also added in these fresh water eco-systems causing pollution and creates health hazards.

Present study is on the taxonomic data of algal species were collected from Dimbhe Dam, It is located on Ghod River at Dimbhe 11 kms away from Ghodegaon in Ambegaon Tehsil.

Water samples were collected periodically from Dimbhe dam. For qualitative analysis, water samples were collected separately in the bottles. Collections were done from streams, rivers, ponds, puddles, and impoundments during and after monsoon season from Ambegaon Tehsil of Pune District. Algae of different habitats were collected from these localities such as - planktonic, benthic, epiphytic, terrestrial, epiphyllous and from tree-trunk.

Planktonic algal collection was made by using plankton net of bloting silk cloth 25 meshes/linear inch and analyzed qualitatively. Phytoplanktons were collected by using phytoplankton net from surface waters of impoundments. Quantitative estimation was done for phytoplankton by Lackey's drop method (Lackey, 1938). Algal identification was carried out by using standard literature and monographs. Microphotographs of algal plants encountered during investigation period were taken.

I have collected 42 algal specimens. These are from single orders of 1 class and 1 division. In which all 42 specimens planktonic specimens

The present investigation shows 1 order, 3 families, 5 genus, 23 species, 18 varieties and 1 forma from 1 division and 1 class. Present investigation shows dominance of Family Gomphonemataceae represented by 21 species while family Surirellaceae represented by 9 species.

\section{CONCLUSIONS}


* This research work helps us to know type of algal flora of the study area.

* The data gathered serves as base line data for planning utilization and conservation strategies of algae.

* Phytoplankton studies helps us to know primary producers (Qualitatively and quantitatively) of the study area.

* This research work may help all the phycological students to study the algal vegetation in Ambegaon.

\section{REFERENCES:}

Anand, N. and Bhishan Singh Mahendra Pal Singh; 'Indian Freshwater Microalgae'; 1997

Gupta, R. K.; 'Algal Flora of Dehradun District Uttaranchal'; B. S. I.:2005

Iyengar, M. O. P. and G. S. Venkataraman; 'The ecology and seasonal succession of the river Cooum at Madras with special reference to the Diatomaceae'; J. Madras Univ. 21:140192:1951

Kumawat, D.A., Y. P. Melche, H. E. Rane, S. B. Patil, R. B. Borse and S. D. Vanjari; 'Diatoms from Southern Satpura Hill anges of Maharashtra Genus Gomphonema Agardh'; J. Indian Botanical Society; Volume 87(1\&2):61-66:2008

Kumawat D.A. and A. K. Jawale; 'Genus Cymbella Agardh from Fish Ponds at Anjale Faizpur, District Jalgaon, Maharashtra, India'; Biology and Biodiversity of Microalgae,
Centre of Advanced Studies in Botany, Chennai, Madras:2009

Mahyavanshi, N.; 'Further studies on the Marine Planktonic Diatoms in the Coastal Waters of Saurashtra'; Phykos 14(1\&2):99-112:1975

Narkhede, P. N.; 'Genus Nitzschia and Surirella from Hatnur dam, Jalgaon district, Maharashtra'; J. Aqua. Biol. 21(2):1922:2006

Narkhede, P. N., O. N. Bhoge and G. Ragothaman; 'Study of some Bacillariophyceae Members from Hartnur Dam in Faizpur, Jalgaon District, Maharashtra, India'; J. Indian Bot. Soc. Vol. 86 (1\&2):44-46:2007

Raghothaman, G. and Johny Thomas; 'Studies on the Diatom Flora of Hajira Coast Gujarat'; Phykos 27:157-160:1988

Sarode, P. T. and N. D. Kamat; 'Diatoms of Marathwada, Maharashtra-II; Phykos 19(2):197:1980

Sarode, P. T. and N. D. Kamat; 'Diatoms of Marathwada, Marathwada Univ. JSD 22(15):13:1983

Sarode, P. T. and N. D. Kamat; 'Freshwater diatoms of Maharashtra'; Saikrupa Prakashan, Aurangabad:1-324:1984

Tagad Radhakisan N., Subhash D. Pingale and Ramchandra H. Bhoge; 'Diatoms from Junnar Tehsil of Pune District (Maharahstra)'; Advances in Plant Sciences; Vol. 25(1):5-14:2012 


\begin{tabular}{|c|c|}
\hline Sr. No. & Name of Algal Specimen \\
\hline Family & Nitzschiaceae \\
\hline Genus & Hantzschia \\
\hline 1 & Hantzschia amphioxys (Ehrenb.) Grunow. v. capitata O. Mull \\
\hline 2 & Hantzschia amphioxys (Ehr.) Grun. v. densestriata (Font.) A. Cl. \\
\hline 3 & Hantzschia amphioxys (Ehr.) Grun. v. mugadensis Gandhi \\
\hline Genus & Nitzschia \\
\hline 1 & Nitzschia apiculata (Gorg.) Grun. \\
\hline 2 & Nitzschia closteriumW. Smith \\
\hline 3 & Nitzschia heufleriana Grun. \\
\hline 4 & Nitzschia heufleriana Grun.v. elongatea Pant. \\
\hline 5 & Nitzschia hungarica Grun. \\
\hline 6 & Nitzschia jugata Gandhi \\
\hline 7 & Nitzschia obtusa W. Smith v. scalpelliformis Grun. \\
\hline 8 & Nitzschia palea (Kuetz.) W. Smith \\
\hline 9 & Nitzschia theramalis kuetz.v .minor Hilse \\
\hline Family & Surirellaceae \\
\hline Genus & Surirella \\
\hline 1 & Surirella apiculata W. Smith \\
\hline 2 & Surirella biseriata Breb. \\
\hline 3 & Surirella carponii Breg \\
\hline 4 & Surirella ovata Kuetz \\
\hline 5 & Surirella ovata Kuetz.v. pinnata (W. Smith) Hustedt \\
\hline 6 & Surirellar obusta Ehr. \\
\hline 7 & Surirella spiralis Kuetzing \\
\hline 8 & Surirella tenera Greg. $v$. nervosa A. S. \\
\hline Genus & Cymatopleura \\
\hline 1 & Cymatopleura solea (Breb) W. Smith \\
\hline Family & Gomphonemataceae \\
\hline Genus & Gomphonema \\
\hline 1 & Gomphonema aequatoriale Hustedt \\
\hline 2 & Gomphonema clavetoides Gandhi v. valida Gandhi \\
\hline 3 & Gomphonema constrictum Ehr. v. capitata (Ehr.) Cleve \\
\hline 4 & Gomphonema constrictum Ehr. $v$. indica Gandhi \\
\hline 5 & Gomphonema gracile Ehr. \\
\hline 6 & Gomphonema gracile Ehr. f. turris Hustedt \\
\hline 7 & Gomphonema gracile Ehr. v. auritumA. Br. \\
\hline 8 & Gomphonema gracile Ehr. v. intricatiforme Mayer \\
\hline 9 & Gomphonema gracile Ehr. v. lanceolate (Kuetz.) Cleve \\
\hline 10 & Gomphonema herbidense (Greg.) Ehr. \\
\hline 11 & Gomphonema intricatum Kuetz v. fossile Pant \\
\hline 12 & Gomphonema lacus-rankala Gandhi v. robusta Gandhi \\
\hline 13 & Gomphonema lancoelatum Ehr. \\
\hline 14 & Gomphonema monantum Schum. $v$. acuminatum Mayer \\
\hline 15 & Gomphonema moniliforme Gandhi \\
\hline 16 & Gomphonema olivaceum (Lyng.) Kuetz. \\
\hline 17 & Gomphonema olivaceoides Hustedt. \\
\hline 18 & Gomphonema parvulum (Kuetz.) Grun. \\
\hline 19 & Gomphonema parvulum (Kuetz.) Grun. v. micropus (Kuetz) Cleve \\
\hline 20 & Gomphonema sphaerophorum Ehr. \\
\hline 21 & Gomphonema subapicatum Fritsch et Rich \\
\hline
\end{tabular}




\section{Plate 1}
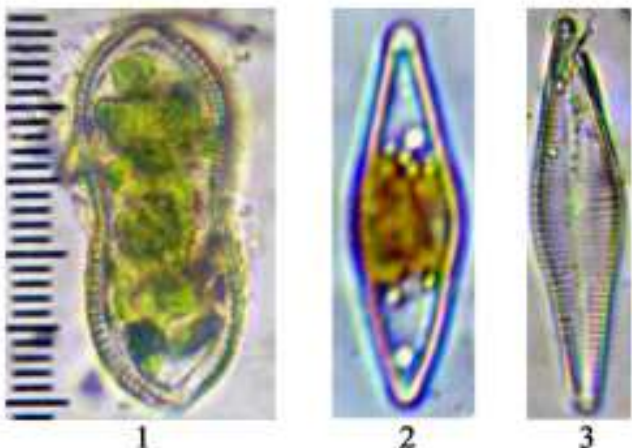

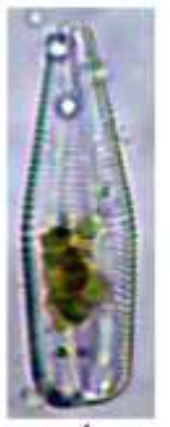

4

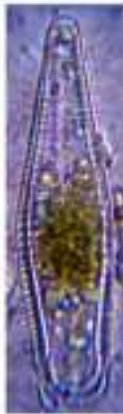

5

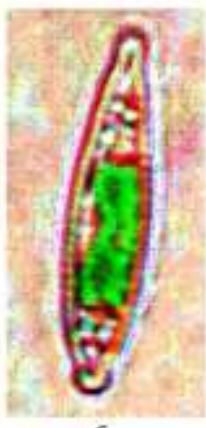

6

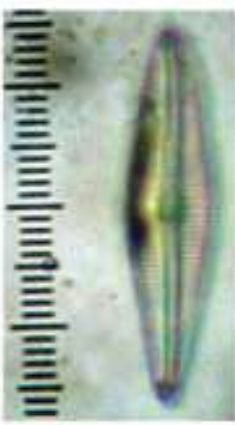

7

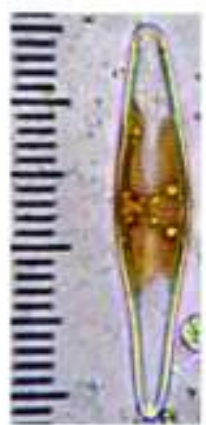

8

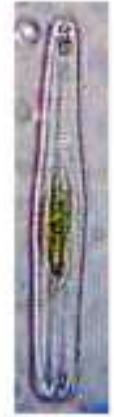

12

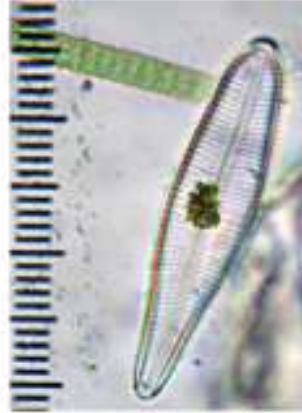

13

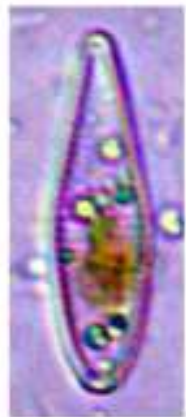

9

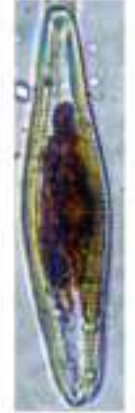

14

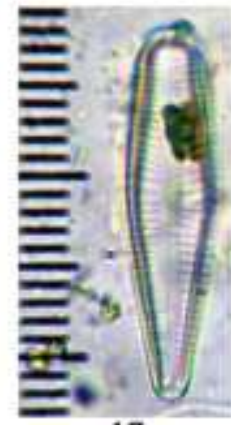

17

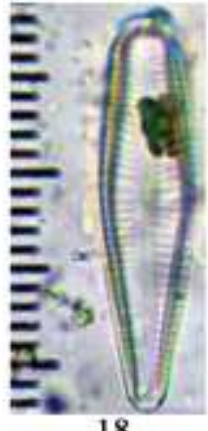

18

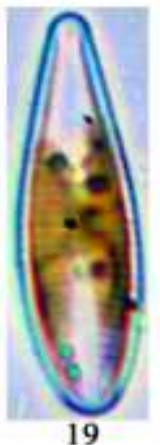

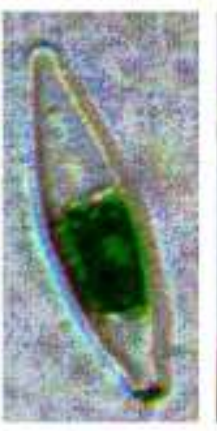

10

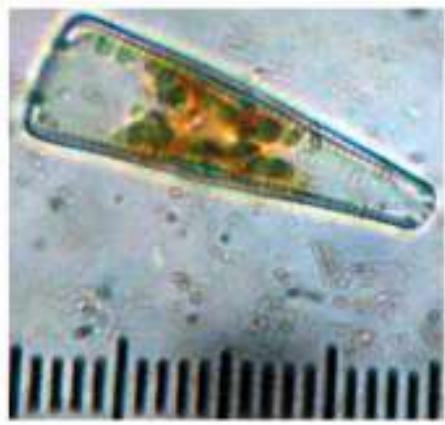

11

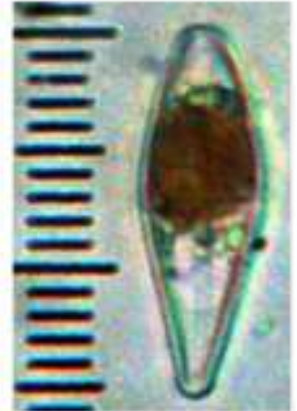

15

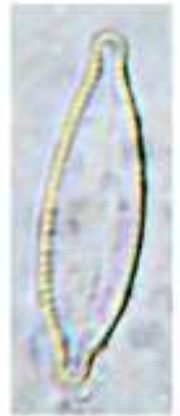

20

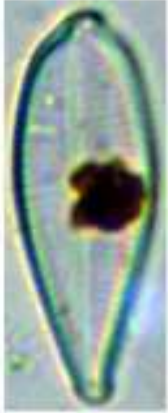

16

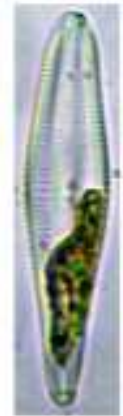

21

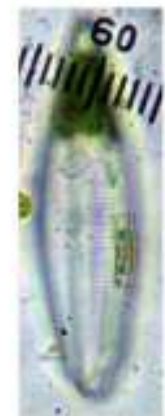

22

Fig. 1) Cymatopleura solea, 2) Gomphonema aequatoriale, 3) Gomphonema clavatoides v. valida, 4) Gomphonema constrictum $v$. capitata, 5) Gomphonema constrictum $v$. indica, 6) Gomphonema gracile $f$. turris, 7) Gomphonema gracile v, auritum, 8) Gomphonema gracile v, intricatiforme, 9) Gomphonema gracile v. lanceolata, 10) Gomphonema gracile, 11) Gomphonema hebridense, 12) Gomphonema intricatum v. fossile, 13) Gomphonema lacusrankala v. robusta, 14) Gomphonema lanceolatum, 15) Gomphonema monantum v. acuminatum, 16) Gomphonema moniliforme, 17) Gomphonema olivacenum, 18) Gomphonema parvulum v. micropus, 19) Gomphonema parvulum, 20) Gomphonema sphaerophorum, 21) Gomphonema subapicatum, 22) Gomphonema subapicatum v. okamurae 
Plate 2
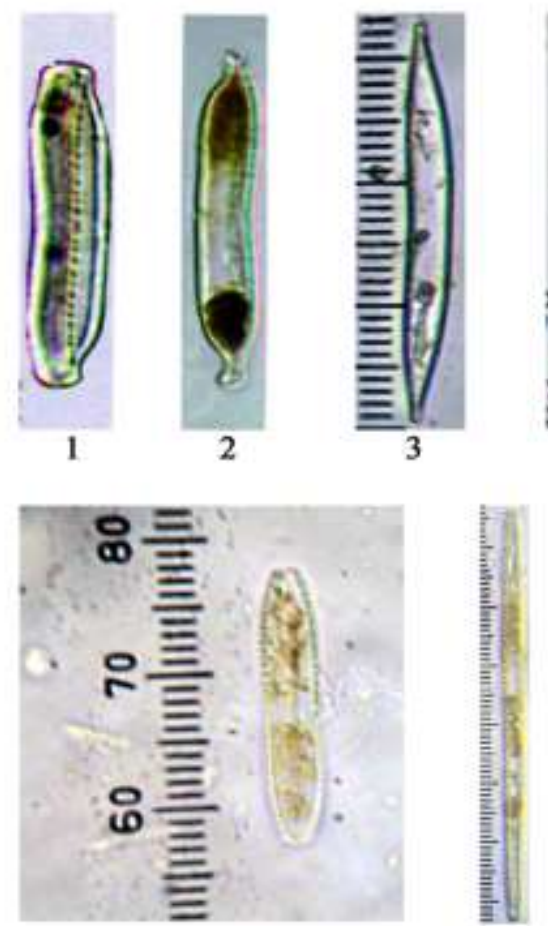

8

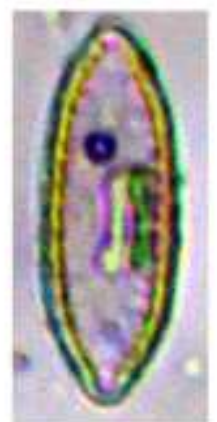

13

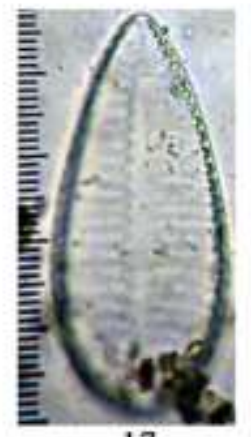

17

9

14
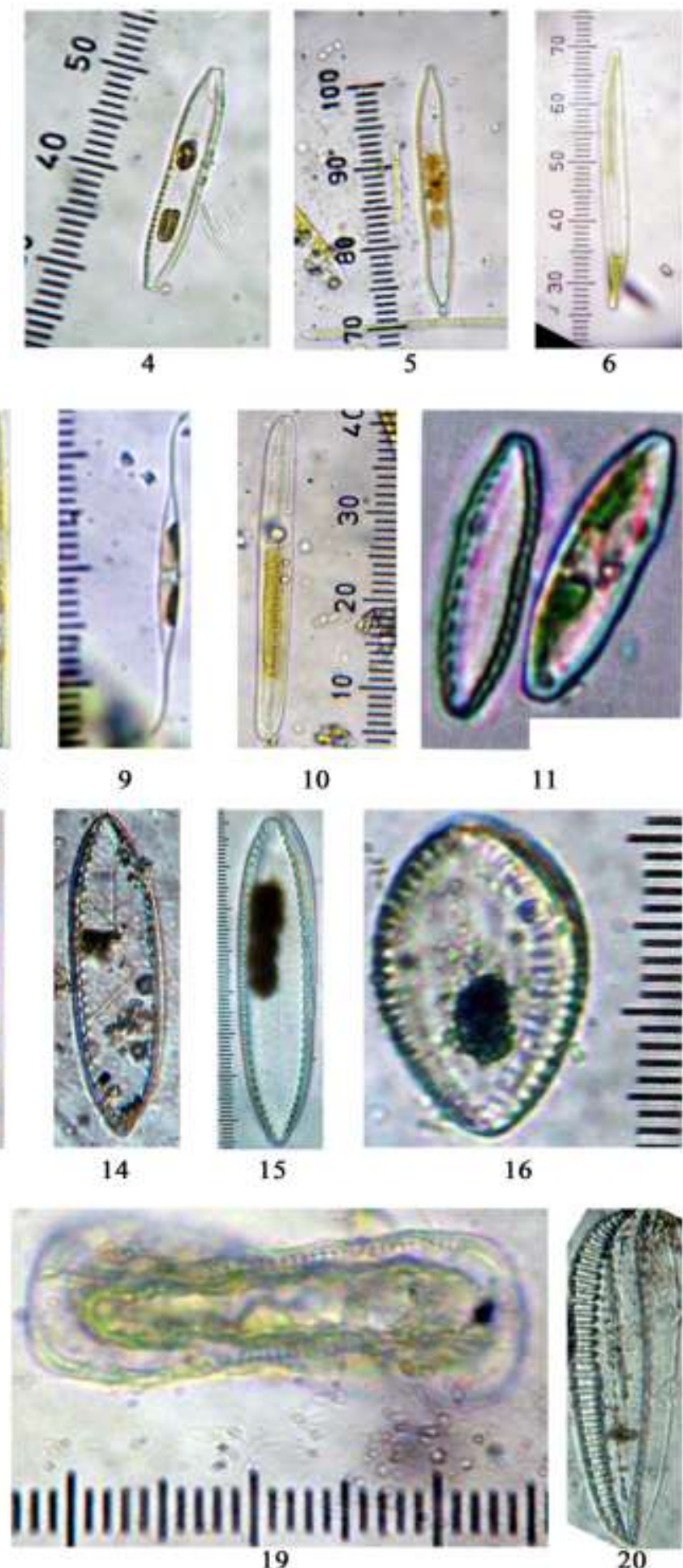

19

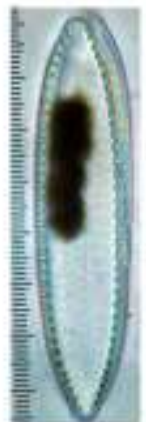

15

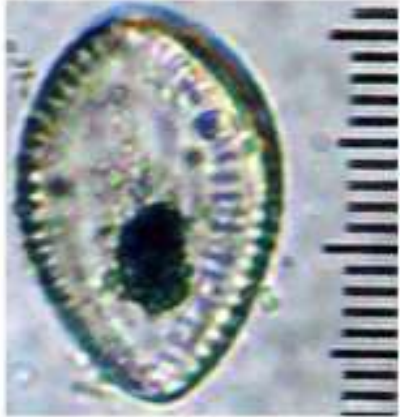

16

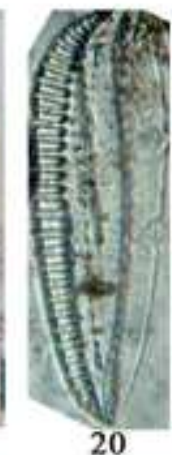

Fig. 1) Hantrschia amphioxys v, capitata, 2) Hantzschia amphioxys v, densestriata, 3) Hantzschia amphioxys v. mugadensis, 4) Nitzschia apiculata, 5) Nitzschia closterrium, 6) Nitzschia heufleriana, 7) Nitzschia heufleriana v. elongata, 8) Nitzschia hungarica, 9) Nitzschia jugata, 10) Nitzschia obtusa v. scalpelliformis, 11) Nitzschia palea, 12) Nitzschia thermalis v. minor, 13) Surirella apiculata, 14) Surirella biseriata, 15) Surirella capronii, 16) Surirella ovata, 17) Surirella ovata v pinnata, 18) Surirella robusta, 19) Surirella spiralis, 20) Surirella tenera v. nervosa 